\title{
Tweede kansen, stigma's en de praktijk van het civielrechtelijk bestuursverbod
}

\author{
Mr. M. Neekilappillaien mr.dr. N.T. Pham*
}

\begin{abstract}
Het civielrechtelijk bestuursverbod biedt de curator en het Openbaar Ministerie een instrument om faillissementsfraude effectiever te bestrijden. Op basis van rechtspraakanalyse en interviews met betrokken curatoren wordt betoogd dat het civielrechtelijk bestuursverbod geen geschikt instrument is voor het aanpakken van onkundige maar bonafide bestuurders.
\end{abstract}

\section{Inleiding}

De Wet civielrechtelijk bestuursverbod is op 1 juli 2016 in werking getreden. ${ }^{1}$ Bijna twee jaar later legt de Rechtbank Den Haag op vordering van de curator gelijktijdig de eerste twee civielrechtelijke bestuursverboden op. Twee betrokkenen wordt daarmee voor een periode van vijf jaar de mogelijkheid ontnomen een rechtspersoon te besturen of daaraan als commissaris verbonden te zijn. ${ }^{2}$ De namen van de betrokkenen zijn voor de duur van het civielrechtelijk bestuursverbod online vindbaar voor eenieder die naar de website van de Kamer van Koophandel $(\mathrm{KvK})$ surft. $^{3}$ Het is denkbaar dat deze persoonsgegevens eeuwig zichtbaar blijven op obscure buitenlandse websites.

Het civielrechtelijk bestuursverbod biedt de curator en het Openbaar Ministerie (OM) een instrument om faillissementsfraude effectiever te bestrijden, namelijk door frauduleuze bestuurders te verhinderen in het voortzetten van hun activiteiten via allerlei omwegen en met nieuwe rechtspersonen. Ook 'onkundige' bestuurders die zich schuldig hebben gemaakt aan wanbestuur in de aanloop naar een faillissement kunnen met een civielrechtelijk bestuursverbod worden geconfronteerd. ${ }^{4}$ De vraag rijst of het wenselijk is om deze

Mr. M. Neekilappillai is als promovenda verbonden aan het Instituut voor Privaatrecht, afdeling Burgerlijk recht, van de Universiteit Leiden. Mr. dr. N.T. Pham is als universitair docent verbonden aan het Instituut voor Privaatrecht, afdeling Ondernemingsrecht, van de Universiteit Leiden.

1. De Faillissementswet werd daardoor aangevuld met art. 106a tot 106e.

2. Rb. Den Haag 13 juni 2018, ECLI:NL:RBDHA:2018:8801.

3. Na afronding van deze bijdrage op 11 mei 2019 heeft de KvK het overzicht van opgelegde civielrechtelijke bestuursverboden met namen van betrokkenen op de webpagina www.kvk.nl/over-de-kvk/overzichtcivielrechtelijk-bestuursverbod/ tijdelijk offline gehaald. De toelichting van de KvK is dat civielrechtelijke bestuursverboden door de KvK zullen worden gepubliceerd na de inwerkingtreding van het gewijzigde Handelsregisterbesluit. Verwacht wordt dat deze wijziging in juli 2020 in werking treedt, zie: www.kvk.nl/over-kvk/overzicht-civielrechtelijkbestuursverbod/. Deze website is laatstelijk geraadpleegd op 30 juli 2019.

4. Kamerstukken II 2013/14, 34011, 3, p. 1 (MvT). 'onkundige' maar goedwillige bestuurders te treffen met een civielrechtelijk bestuursverbod.

De opbouw van deze bijdrage is als volgt. Eerst wordt kort de ratio achter en de vormgeving van het civielrechtelijk bestuursverbod uiteengezet (par. 2). Vervolgens staan de reeds gevoerde rechtszaken over het opleggen van een civielrechtelijk bestuursverbod centraal. Op basis van interviews met betrokken curatoren wordt inzicht gegeven in de motivatie van deze curatoren om al dan niet een civielrechtelijk bestuursverbod te vorderen (par. 3). Daarna volgt een reflectie op het civielrechtelijk bestuursverbod, waarbij de vraag wordt besproken of het civielrechtelijk bestuursverbod de onkundige maar bonafide bestuurder een tweede kans na faillissement ontneemt vanwege het sociale stigma dat aan het bestuursverbod kleeft (par. 4). Wij sluiten af met aanbevelingen (par. 5).

\section{Het civielrechtelijk bestuursverbod}

\subsection{De beleidsdoelstelling van het civielrechtelijk bestuursverbod}

De wetgever beoogt met het civielrechtelijk bestuursverbod de samenleving te beschermen tegen enerzijds frauduleuze bestuurders die rechtspersonen met beperkte aansprakelijkheid willen misbruiken en anderzijds bonafide bestuurders die niet verantwoordelijk kunnen omgaan met het voorrecht van beperkte aansprakelijkheid. Naast faillissementsfraude kunnen ook aperte onregelmatigheden in of rondom een faillissement effectiever bestreden worden, zoals de ernstige tegenwerking van de curator, faillissementsrecidive en de benadeling van crediteuren voorafgaand aan een faillissement. ${ }^{6}$ In maart 2013 publiceerde de toenmalige minister van Veiligheid en Justitie het concept-wetsvoorstel Wet civielrechtelijk bestuursverbod. Dit concept-wetsvoorstel, en de meerwaarde van het civiel-

5. Een parallel met bestuurdersaansprakelijkheid laat zien dat in de meerderheid van de bestuurdersaansprakelijkheidszaken waarbij de bestuurders aansprakelijk zijn gehouden, sprake was van pertinent malafide gedragingen ( $57 \%$ tegenover $43 \%$ ), zie: N.T. Pham, Directors' liability. A legal and empirical study (diss. Rotterdam), Deventer: Wolters Kluwer 2017 , p. 69.

6. MvT, p. 1 . 
rechtelijk bestuursverbod in het algemeen, werden in de consultatiereacties en literatuur stevig bekritiseerd. ${ }^{7}$

\subsection{De gronden voor oplegging en de discretionaire rechterlijke bevoegdheid}

De rechtbank kan op vordering van de curator of op verzoek van het OM een civielrechtelijk bestuursverbod van maximaal vijf jaar opleggen aan de (gewezen) bestuurder ${ }^{8}$ van een privaatrechtelijke rechtspersoon ${ }^{9}$ als tijdens of in de drie jaren voorafgaand aan het uitspreken van het faillissement van die rechtspersoon sprake is van een situatie zoals geschetst in artikel 106 lid 1 sub a tot en met e Faillissementswet (Fw). Vanwege het ingrijpende karakter van een civielrechtelijk bestuursverbod kan de betrokkene hoger beroep en cassatie instellen. ${ }^{10}$

Ook de bestuurder van een (gewezen) rechtspersoon-bestuurder (art. 106a lid $2 \mathrm{Fw}),{ }^{11}$ de natuurlijke persoon die handelt of heeft gehandeld in de uitoefening van een beroep of bedrijf (art. 106a lid $4 \mathrm{Fw}$ ), de uitvoerende bestuurder in het geval van een monistisch bestuur (art. 106d lid $2 \mathrm{Fw}$ ) en de beleidsbepaler of de indirecte bestuurder (art. 106d lid $1 \mathrm{Fw}$ ) kunnen met een civielrechtelijk bestuursverbod worden geconfronteerd. De wetgever heeft bewust ervoor gekozen om de commissaris en de niet-uitvoerende bestuurder niet onder deze reikwijdte te laten vallen. ${ }^{12}$

7. Voor een uitgebreide kritische beschouwing over het civielrechtelijk bestuursverbod, zie: F.E. Keijzer \& M.L. Lennarts, Het civielrechtelijk bestuursverbod: geen medicijn maar een placebo, in: D. Busch e.a. (red.), Wet continuïteit van ondernemingen (delen I en II) en het bestuursverbod (Vereeniging 'Handelsrecht' Preadviezen 2014), Zutphen: Uitgeverij Paris 2014. Keijzer en Lennarts maken hierbij onderscheid tussen literatuur die zeer kritisch is (p. 124) (bijv. D.R. Doorenbos, Het civielrechtelijk bestuursverbod voor faillissementsfraudeurs: een ambivalent voorstel, AA 2014, p. 19-23; G.J.A. van Leeuwen \& A.D.M. Bras, Het conceptwetsvoorstel civielrechtelijk bestuursverbod, een uitzonderlijke situatie, TvOB 2013, p. 204-210; M.L. Lennarts, Boeven vangen op kosten van de boedel? De curator als hoeder van het algemeen belang? Geen goed plan!, TvI 2013/26 en F.E. Keijzer, Het Voorontwerp civielrechtelijk bestuursverbod: onvoldoende doordachte daadkracht?, Ondernemingsrecht 2013/115) en literatuur die kritisch is, maar met voorstellen voor verbetering, ontleend aan het Engelse civielrechtelijk bestuursverbod (bijv. M. Neekilappillai, Naar een effectieve vormgeving van het civielrechtelijk bestuursverbod. Lessen uit de Engelse Company Directors Disqualification Act 1986, Ondernemingsrecht 2014/84, p. 411-416 en R.J. Philips, Wetsvoorstel Wet civielrechtelijk bestuursverbod, FIP 2013, afl. 4 p. 114-121). Zie verder par. 3.3 ('Aanpassingen ten opzichte van het voorontwerp') van het preadvies voor verwijzingen naar kritische consultatiereacties.

8. 'Om te voorkomen dat bestuurders zich aan een civielrechtelijk bestuursverbod kunnen onttrekken door in het zicht van of kort voor een faillissement bewust te defungeren', aldus de MvT, p. 14.

9. In de zin van art. 2:3 BW, namelijk verenigingen, coöperaties, onderlinge waarborgmaatschappijen, nv's, bv's en stichtingen. Ook Europese Economische Samenwerkingsverbanden, Europese vennootschappen en Europese coöperatieve vennootschappen met een statutaire zetel in Nederland vallen hier ex art. 106e Fw onder.

10. MvT, p. 14

11. De rechtspersoon-bestuurder die zelf door een rechtspersoon wordt bestuurd, valt onder art. 106a lid 2 Fw, aldus de MvT, p. 22-23.

12. MvT, p. 15
De oplegging van een civielrechtelijk bestuursverbod wordt, behoudens disculpatie ex artikel 106a lid $1 \mathrm{Fw}$, gerechtvaardigd geacht wanneer sprake is van een van de vijf ${ }^{13}$ limitatief opgesomde situaties:

- Door de rechter is bij onherroepelijk geworden uitspraak geoordeeld dat de bestuurder voor zijn handelen of nalaten bij die rechtspersoon aansprakelijk is op grond van artikel 2:138/2:248 Burgerlijk Wetboek (BW) (a-grond).

- De bestuurder heeft doelbewust namens de rechtspersoon paulianeuze rechtshandelingen verricht, toegelaten of mogelijk gemaakt waardoor schuldeisers aanmerkelijk zijn benadeeld en die overeenkomstig artikel 42 of $47 \mathrm{Fw}$ bij onherroepelijk geworden uitspraak door de rechter zijn vernietigd (b-grond).

- De bestuurder schiet, ondanks een verzoek van de curator, in ernstige mate tekort jegens de curator in de nakoming van zijn informatie- of medewerkingsverplichtingen voortvloeiend uit de $\mathrm{Fw}$ (c-grond).

- De bestuurder is minstens tweemaal betrokken geweest bij een faillissement van een rechtspersoon of als natuurlijke persoon handelend in de uitoefening van een beroep of bedrijf, en daarvan treft hem een persoonlijk verwijt (d-grond).

- Aan de rechtspersoon of de bestuurder is een fiscale vergrijpboete opgelegd, en deze beschikking is onherroepelijk geworden (e-grond).

Kortom, er moet sprake zijn van een ernstig persoonlijk verzuim van de bestuurder. Dit is direct dan wel indirect tot uitdrukking gebracht in de vijf gronden in artikel 106a lid 1 sub a tot en met e Fw. De bewijslast ligt bij de curator of het OM. De betrokken bestuurder kan tegenbewijs leveren door aannemelijk te maken dat hem geen of onvoldoende verwijt treft. ${ }^{14}$ De gronden in artikel 106 lid 1 sub b tot en met e Fw gelden ook voor de eenmanszaak, de cv en de vof. ${ }^{15}$

Indien de bestuurder zich niet kan disculperen, kan de rechtbank een civielrechtelijk bestuursverbod opleggen van maximaal vijf jaar (art. 106b lid $1 \mathrm{Fw}$ ). De wetgever geeft in de memorie van toelichting aanwijzingen aan de rechter hoe hij zijn discretionaire bevoegdheid kan gebruiken. Vooropstaat dat de rechter alle omstandigheden van het concrete geval dient te betrekken in zijn afweging om al dan niet een bestuursverbod op te leggen of om de duur ervan te bepalen. ${ }^{16}$

13. Indien de Wet continuïteit ondernemingen I door de Eerste Kamer wordt aangenomen, dan wordt een zesde grond ingevoerd (art. 106a lid 1 sub f Fw). De f-grond maakt het mogelijk om oneigenlijk gebruik van de pre-packregeling te sanctioneren met oplegging van een civielrechtelijk bestuursverbod. Zie: Kamerstukken II 2014/15, 34218, 3 (MvT), p. 3 , 10, 21, 49 en 60, Kamerstukken II 2014/15, 34011, 6, p. 2, en het wetgevingstraject op www.eerstekamer.nl/wetsvoorstel/34218_wet_ continuiteit.

14. MvT, p. 17.

15. MvT, p. 23.

16. MvT, p. 15 en 16. 


\subsection{De gevolgen van een civielrechtelijk bestuursverbod}

Het civielrechtelijk bestuursverbod begint op de dag dat de uitspraak van de rechtbank onherroepelijk wordt. Voor de duur van het bestuursverbod kan de betrokkene niet tot bestuurder van of commissaris bij een rechtspersoon benoemd worden. Een benoeming bij een privaatrechtelijke rechtspersoon in strijd met een bestuursverbod is nietig. Ook kan de betrokkene ingevolge artikel 106b lid $2 \mathrm{Fw}$ niet langer als bestuurder of commissaris functioneren bij alle andere rechtspersonen waar hij deze functie bekleedt. Dit is slechts anders wanneer de rechtbank in haar uitspraak bepaalt dat de betrokkene bijvoorbeeld nog wel als bestuurder bij een lokale schaakvereniging of zijn pensioen- of stamrecht-bv kan aanblijven. ${ }^{17}$

De rechter kan een civielrechtelijk bestuursverbod van maatwerk voorzien ex artikel 106b lid $4 \mathrm{Fw}$. De rechtbank is namelijk bevoegd de gevolgen van een bestuursverbod nader te regelen. Zo kan de rechtbank het bestuursverbod tussentijds beëindigen of voortijdig opheffen. ${ }^{18}$ Daarnaast biedt artikel 106 lid $4 \mathrm{Fw}$ de rechter de ruimte om te bepalen dat een bestuursverbod pas intreedt na een bepaalde periode, bijvoorbeeld omdat het nodig kan zijn om derde rechtspersonen enige tijd te geven om nieuwe bestuurders aan te trekken. ${ }^{19} \mathrm{De}$ rechter dient rechtspersonen waarbij de betrokkene bestuurder of commissaris is ex artikel 106c lid $2 \mathrm{Fw}$ om hun zienswijze te vragen over het gevraagde bestuursverbod en de mogelijke gevolgen daarvan.

Het civielrechtelijk bestuursverbod betreft overigens geen algeheel verbod om te ondernemen of een verbod op aandeelhouderschap. ${ }^{20}$ Het staat de betrokkene vrij om als natuurlijke persoon te handelen in de uitoefening van een beroep of bedrijf, waarbij hij zich niet meer kan 'hullen in het kleed van een rechtspersoon om zich aan de persoonlijke aansprakelijkheid te onttrekken'. ${ }^{21}$ Het drijven van een eenmanszaak met persoonlijke aansprakelijkheid biedt daardoor de betrokkene nog de mogelijkheid om in zijn levensonderhoud te voorzien, aldus de gedachte van de wetgever. ${ }^{22}$

De rechtbank kan om naleving van haar uitspraak te verzekeren een dwangsom aan de betrokkene opleggen ex artikel 106b lid $5 \mathrm{Fw}$. Als de dwangsom wordt verbeurd, komt deze toe aan de boedel of, als daarvan geen sprake is, aan de staat. De onherroepelijke uitspraak van de rechtbank of het gerechtshof waarin het bestuursverbod is opgelegd, wordt door de griffier aan de $\mathrm{KvK}$ aangeboden, die dan onverwijld de betreffende persoon als bestuurder uit het Handelsregister uitschrijft. Ook wordt het bestuursverbod, voor de duur waarvoor het is opgelegd, geregistreerd bij het Handelsregister (art. 106b lid 3 Fw). Eenieder kan voor de duur van het bestuursverbod op de web- site van de $\mathrm{KvK}$ raadplegen welke betrokkenen een bestuursverbod opgelegd hebben gekregen. ${ }^{23}$

\subsection{Het toezicht door de rechter-commissaris op de belangenafweging van de curator}

De curator heeft ingevolge artikel $68 \mathrm{Fw}$ altijd voorafgaande instemming van de rechter-commissaris nodig om een civielrechtelijk bestuursverbod te vorderen. Zo kan worden voorkomen dat de curator lichtvaardig gebruikmaakt van deze procedure. De bestuurder hoeft, zogezegd, niet te vrezen voor een willekeurig of ongebreideld optreden van de curator. ${ }^{24} \mathrm{De}$ rechter-commissaris ziet erop toe dat de curator een juiste afweging heeft gemaakt tussen de kosten en het publieke belang dat met de vordering van een civielrechtelijk bestuursverbod is gemoeid en het belang van boedelmaximalisatie ten bate van de gezamenlijke schuldeisers. Indien de gefailleerde vindt dat de curator misbruik maakt van zijn vorderingsbevoegdheid door deze als oneigenlijk dwangmiddel tegen de gefailleerde in te zetten, dan kan hij hierover beklag doen bij de rechter-commissaris ex artikel 69 Fw. Eveneens kunnen schuldeisers zich ingevolge artikel $69 \mathrm{Fw}$ tot de rechter-commissaris wenden als de curator tegen de wens van de schuldeisers afziet van een vordering tot het opleggen van een bestuursverbod. De rechter-commissaris beslist vervolgens, nadat hij de curator heeft gehoord, of de curator alsnog een vordering tot het opleggen van een bestuursverbod moet indienen. ${ }^{25}$

\section{Het civielrechtelijk bestuursverbod in de rechtspraktijk}

\subsection{Inleiding}

Sinds de inwerkingtreding van het civielrechtelijk bestuursverbod per 1 juli 2016 hebben rechtbanken op vordering van de curator of op verzoek van het OM vijf civielrechtelijke bestuursverboden opgelegd. In de databank rechtspraak.nl zijn vier uitspraken gevonden op basis van de zoektermen 'civielrechtelijk bestuursverbod' en 'bestuursverbod' in de periode 1 juli 2016-1 april 2019. Zie tabel 1. In deze paragraaf bespreken wij deze eerste praktijkervaringen met het civielrechtelijk bestuursverbod. Daarbij is gebruikgemaakt van rechtbankuitspraken, openbare faillissementsverslagen en telefonische interviews. Wij hebben in de periode maart-april 2019 drie curatoren geïnterviewd. De gesprekken duurden 30 tot 45 minuten. Ons verzoek om de betrokken officier van justitie in twee zaken te interviewen, werd helaas niet toegewezen. De

\footnotetext{
17. MvT, p. 25.

18. MvT, p. 24 en 26

19. MvT, p. 26

20. MvT, p. 5.

21. MvT, p. 15

22. MvT, p. 5.
}

23. www.kvk.nl/over-de-kvk/overzicht-civielrechtelijk-bestuursverbod/. Zie voetnoot 3 voor toelichting waarom het overzicht van civielrechtelijke bestuursverboden tijdelijk niet via de website van de KvK raadpleegbaar is.

24. MvT, p. 10 en 15.

25. MvT, p. 4. 
Tabel 1 Opgelegde civielrechtelijke bestuursverboden tussen 1 juli 2016 en 1 april 2019

\begin{tabular}{|c|c|c|c|c|c|c|}
\hline $\mathbf{N}$ & Eiser & $\begin{array}{l}\text { Duur in } \\
\text { maanden }\end{array}$ & Dwangsom & Grondslag* & Registratie KvK & Onderliggende uitspraak \\
\hline 1 & Curator & 60 & Niet gevorderd & art. 106a lid $1 \mathrm{Fw}$ & $\mathrm{Ja}$ & $\begin{array}{l}\text { Rb. Den Haag } 13 \text { juni } 2018, \\
\text { ECLI:NL:RBDHA:2018:8801 }\end{array}$ \\
\hline 2 & Curator & 60 & Niet gevorderd & art. 106a lid $1 \mathrm{Fw}$ & $\mathrm{Ja}$ & $\begin{array}{l}\text { Rb. Den Haag } 13 \text { juni } 2018, \\
\text { ECLI:NL:RBDHA:2018:8801 }\end{array}$ \\
\hline 3 & Curator & 24 & Nee & $\begin{array}{l}\text { art. 106a lid } 1 \text { sub } \\
\text { a en c Fw }\end{array}$ & Nee & $\begin{array}{l}\text { Rb. Rotterdam } 14 \text { november } \\
\text { 2018, ECLI:NL:RBROT: } \\
\text { 2018:9777 }\end{array}$ \\
\hline 4 & $\mathrm{OM}$ & 60 & $\mathrm{Ja}$ & $\begin{array}{l}\text { art. 106a lid } 1 \text { sub } \\
\text { d Fw }\end{array}$ & Nee & $\begin{array}{l}\text { Rb. Midden-Nederland } \\
\text { 19 december 2018, } \\
\text { ECLI:NL:RBMNE:2018:6261 }\end{array}$ \\
\hline 5 & $\mathrm{OM}$ & 60 & $\mathrm{Ja}$ & $\begin{array}{l}\text { art. 106a lid } 1 \text { sub } \\
\text { c Fw }\end{array}$ & Nee & $\begin{array}{l}\text { Rb. Amsterdam } 24 \text { januari } \\
\text { 2019, ECLI:NL:RBAMS: } \\
\text { 2019:466 }\end{array}$ \\
\hline
\end{tabular}

${ }^{*}$ Deze grondslagen zijn expliciet benoemd in de uitspraken.

interviews zijn afgenomen op basis van een topic list. ${ }^{26}$ Voorafgaand aan deze publicatie is onderhavige bijdrage, in het bijzonder de hiernavolgende citaten en de geschetste omstandigheden uit de interviews, aan de geïnterviewde curatoren voorgelegd.

De interviewresultaten bieden, als aanvulling op de openbare faillissementsverslagen en primaire rechtsbronnen, meer inzicht in de drijfveren van de betrokken curatoren om al dan niet een civielrechtelijk bestuursverbod te vorderen. Daarnaast bieden de interviewresultaten inzicht in hoe de curatoren het civielrechtelijk bestuursverbod percipiëren. Zo kan de wetgever voorschrijven dat de curator onder omstandigheden een wettelijke taak heeft het publieke belang van faillissementsfraudebestrijding te dienen, maar de curator kan een andere taakopvatting hebben. In deze paragraaf staan nadrukkelijk de subjectieve belevingswereld en overwegingen van de curator centraal.

\subsection{De vordering van het civielrechtelijk bestuursverbod door de curator}

\section{Civielrechtelijk bestuursverbod 1 en 2}

De Rechtbank Den Haag legde bij verstekvonnis op vordering van curator L.J. van Apeldoorn de twee (middellijke) bestuurders van de gefailleerde zorgonderneming Prestige B.V.

26. In de interviews zijn de volgende onderwerpen, indien relevant, aan de orde gekomen: (1) motivatie van de curator om een civielrechtelijk bestuursverbod te vorderen; (2) het belang van crediteuren bij de vordering; (3) de rol en de beoordeling van de rechter-commissaris; (4) kwalificatie van het bestuursverbod als hoofd/nevenvordering door de betrokken curator; (5) bijzonderheden in de betrokken zaak; (6) eventuele rol van FIOD en OM; en (7) de waardering van het vonnis door de betrokken curator. een civielrechtelijk bestuursverbod op voor de maximale duur van vijf jaar. Daarnaast besliste de rechtbank dat de bestuurders - het ging in casu om een echtpaar - hun bestuurstaken onbehoorlijk hadden vervuld en dat dit handelen een belangrijke oorzaak van het faillissement is waardoor zij hoofdelijk aansprakelijk zijn voor het boedeltekort. ${ }^{27}$ Opmerkelijk is dat de rechtbank de gronden voor het opleggen van de civielrechtelijke bestuursverboden expliciteert noch motiveert. Dit klemt temeer nu zij haar vonnis bij verstek heeft gewezen. De rechtbank overweegt slechts dat bestuurders 'het bepaalde in artikel 106a van de Faillissementswet (Fw) geheel of ten dele hebben overtreden'. ${ }^{28}$

Duidelijk is dat het onbehoorlijke bestuur van Prestige B.V. een grond vormt voor de oplegging van het bestuursverbod. Op basis van de openbare faillissementsverslagen en het interview met Van Apeldoorn blijkt dat de vaststelling van de bestuurdersaansprakelijkheid ex artikel 2:248 lid $2 \mathrm{BW}$ in het feit moet hebben gelegen dat de jaarrekeningen nooit gedeponeerd waren (a-grond). De bestuurders zijn volgens Van Apeldoorn eveneens betrokken geweest bij meerdere faillissementen waarbij schuldeisers onbetaald bleven (d-grond). Ook vermoedde de curator dat de bestuurders paulianeus hadden gehandeld (b-grond). Uit het faillissementsverslag blijkt verder dat Van Apeldoorn aangifte heeft gedaan tegen de bestuurders wegens vermoeden van verduistering van goederen waar de Belastingdienst beslag op had gelegd, en omdat bestuurders in het geheel niet meewerkten aan de afwikkeling

27. Rb. Den Haag 13 juni 2018, ECLI:NL:RBDHA:2018:8801, r.o. 3.5. 28. Rb. Den Haag 13 juni 2018, ECLI:NL:RBDHA:2018:8801, r.o. 3.1. 
van het faillissement - zij waren lange tijd onvindbaar (c-grond). ${ }^{29}$

Op basis van zijn bevindingen heeft Van Apeldoorn contact opgenomen met de Rechtbank Haarlem. In overleg met de rechter-commissaris en de Belastingdienst heeft de rechtercommissaris toestemming gegeven voor de procedure om bij wijze van test case een civielrechtelijk bestuursverbod te vorderen. Dit voorstel kon eveneens rekenen op steun van de schuldeisers, die bestonden uit een aantal werknemers en de Belastingdienst. Allen waren het erover eens dat de betrokken bestuurders gestopt moesten worden. De Belastingdienst was meermalen door dezelfde bestuurders benadeeld en Van Apeldoorn begreep van de Inspectie voor de Gezondheidszorg dat de fraude in de thuiszorgbranche groot is. De Inspectie voor de Gezondheidszorg verzocht Van Apeldoorn er alles aan te doen om te voorkomen dat deze bestuurders hun malafide praktijken zouden kunnen voortzetten. Van Apeldoorn liep naar eigen zeggen al gauw tegen de kosten van de procedure aan:

'Deze zaak viel niet onder de garantieregeling voor curatoren, ook omdat er geen verhaal wordt geboden. De Belastingdienst was bereid een boedelbijdrage te leveren van een paar duizend euro. Dit dekte totaal niet de kosten, maar ik dacht: als curator is het geven en nemen. Je hebt een packagedeal met de rechtbank. Daar zitten faillissementen bij waar je wel je salaris uit krijgt, en je hebt faillissementen waar een maatschappelijk belang bij is.'

In het interview benadrukte Van Apeldoorn dat de steun van schuldeisers en de tegemoetkoming van de Belastingdienst cruciaal voor hem waren om een procedure te starten:

'Er moet echt wel wat aan de hand zijn om iemand te dagvaarden louter op de grond van artikel 106a. De houding van curatoren is sowieso al vrij afwachtend, omdat het maar de vraag is of zij daarvoor betaald gaan worden. Al zou de overheid komen met een vast bedrag, dan is het maar de vraag of dit kostendekkend is. Ik denk van niet. Ik sta er makkelijker in dan andere curatoren, omdat ik vind dat bij bepaalde momenten het er ook bij hoort dat je als curator iets verder gaat. Ik zeg heel eerlijk dat ik me afvraag of alle curatoren er zo in zullen staan. Dus ik denk dat opgepast moet worden dat het artikel in de praktijk een dode letter is, als er niks met de kosten gebeurt.'

In casu speelde bovendien het rechtvaardigheidsgevoel van de schuldeisers een grote rol en het bestuursverbod bleek een mooi instrumentarium, zoals Van Apeldoorn het verwoordde:

'Ik ben door een aantal crediteuren opgebeld. Ook werknemers. Je zag heel duidelijk dat het rechtvaardigheidsgevoel van de mensen een belangrijke rol speelde in hun

29. Openbaar faillissementsverslag rechtspersoon (ex art. 73A Fw), insolventienummer F.15/17/232, verslag van 3 oktober 2017, par. 8.8. wens om die bestuurders aan te pakken. In deze casus schiet je er niets mee op om een procedure te beginnen. Maar het bestuursverbod was hier een van de weinige manieren om te proberen deze bestuurders te stoppen. Ik denk toch dat het de bedoeling van de wet is om een signaalfunctie af te geven: pas op, je kunt ook een bestuursverbod van vijf jaar krijgen. Dat kunnen mensen als vervelend ervaren. Ik denk dat alle kleine beetjes helpen.'

Of de bestuurders daadwerkelijk vervolgd zullen worden door het OM blijft onduidelijk. ${ }^{30}$ Van Apeldoorn heeft na zijn aangifte niets meer vernomen van het OM. De Rechtbank Den Haag laat in haar vonnis de eventuele vermeende frauduleuze gedragingen van de bestuurders buiten beschouwing. Evenmin vermeldt de Rechtbank Den Haag in haar vonnis dat de curator aangifte heeft gedaan tegen de bestuurders van Prestige B.V. Van Apeldoorn heeft uiteindelijk alsnog telefonisch contact met de bestuurders gehad, die bereid waren om te verklaren dat zij afstand doen van hoger beroep, waarmee zij ook te kennen gaven dat zij het vonnis hebben ontvangen en gelezen. Het vonnis is inmiddels in kracht van gewijsde gegaan, waarmee de vaststelling van bestuurdersaansprakelijkheid en de bestuursverboden onherroepelijk zijn geworden. ${ }^{31}$ De bestuursverboden zijn dan ook met naam en toenaam van de betrokkenen geregistreerd in het openbare Handelsregister van de $\mathrm{KvK}^{32}$

\section{Civielrechtelijk bestuursverbod 3}

In het faillissement van CSH Uitzendbureau B.V. vorderde de curator, E.J. Luten, dat de Rechtbank Rotterdam de betrokken bestuurder een civielrechtelijk bestuursverbod van vijf jaar op zou leggen op de gronden a en c van artikel 106a lid 1 Fw. ${ }^{33}$ Daarbij vorderde de curator ook oplegging van een dwangsom van $€ 1000$ per dag waarop de betrokkene niet aan dit bestuursverbod voldoet. Bij tussenvonnis van 9 mei 2018 vroeg de Rechtbank Rotterdam ex artikel 106c lid 2 Fw de curator van twee gefailleerde vennootschappen om een zienswijze over het gevraagde bestuursverbod en de mogelijke gevolgen daarvan. De Rechtbank Rotterdam overweegt in r.o. 4.3. dat 'de mogelijkheid van een doorstart van de vennootschap, bijvoorbeeld door het aanbieden van een akkoord, nog bestaat'. ${ }^{34}$

De Rechtbank Rotterdam wees bij vonnis van 14 november 2018 de vordering tot oplegging van het civielrechtelijk bestuursverbod toe ex artikel 106a lid 1 sub a en c Fw, maar matigde de duur van het bestuursverbod tot twee jaar en wees

30. Openbaar faillissementsverslag rechtspersoon (ex art. 73A Fw), insolventienummer F.15/17/232, verslag van 14 januari 2019, par. 10.1.

31. Openbaar faillissementsverslag rechtspersoon (ex art. 73A Fw), insolventienummer F.15/17/232, verslag van 14 januari 2019, par. 9.3.

32. www.kvk.nl/over-de-kvk/overzicht-civielrechtelijk-bestuursverbod/; zie ook voetnoot 3 voor toelichting.

33. Rb. Rotterdam 14 november 2018, ECLI:NL:RBROT:2018:9777, r.o. 3.18 .

34. Rb. Rotterdam 9 mei 2018, ECLI:NL:RBROT:2018:3747, r.o. 4.1-4.4. 
de gevorderde dwangsom af. ${ }^{35} \mathrm{Zij}$ kwam tot dit oordeel, in de eerste plaats, omdat de bestuurdersaansprakelijkheid met name is gebaseerd op de schending van de publicatieplicht: de bestuurder heeft de jaarstukken van 2013, 2014 en 2015 niet tijdig gedeponeerd en het is niet aannemelijk geworden dat er andere belangrijke oorzaken van het faillissement zijn geweest. De bestuurder kon het wettelijke bewijsvermoeden van artikel 2:248 lid 2 BW niet ontzenuwen door enkel te verwijzen naar 'de wereldwijde crisis' alsook het wegvallen van opdrachtgevers zonder nader uiteen te zetten welke gevolgen dit had voor de vennootschap, aldus de rechtbank. ${ }^{36}$ Echter, omdat de te late deponering van de jaarstukken van 2013 en 2014 speelt in de periode van vóór 1 juli 2016, kan dit op grond van het overgangsrecht niet worden meegenomen bij het opleggen van het bestuursverbod. ${ }^{37}$ In de tweede plaats oordeelde de rechtbank dat de schending van de informatieplicht door de bestuurder jegens de curator ernstig is, maar beperkt in duur en omvang. Niettemin was de Rechtbank Rotterdam resoluut: het veiligstellen van de digitale en fysieke administratie komt voor rekening en risico van de bestuurder. De bestuurder heeft een brengplicht, de curator heeft geen haalplicht. ${ }^{38}$ Daarbovenop overweegt de rechtbank in r.o. 3.17: 'Doordat de administratie als gevolg van de handelwijze van [gedaagde] is vernietigd, heeft de curator hier geen gedegen onderzoek naar kunnen doen en niet kunnen vaststellen of sprake is geweest van fraude.'

Wij stellen vast dat in de rechtbankuitspraak (vermoedens van) malafide gedragingen niet aan de orde zijn gekomen of vastgesteld. Noch blijkt uit de faillissementsverslagen en het interview met Luten dat hij aangifte tegen de bestuurder heeft gedaan. Wel liet Luten weten dat hij paulianeus handelen vermoedde en dat de betrokken bestuurder een recidivist was in de zin dat deze betrokken was bij twee voorgaande faillissementen en parallel aan het faillissement van CSH Uitzendbureau B.V. eveneens betrokken is bij een ander faillissement. In al deze gevallen liet de betrokken bestuurder schuldeisers onbetaald. In overleg met de Belastingdienst, die welwillend stond tegenover een procedure tot oplegging van een bestuursverbod, heeft Luten besloten daartoe over te gaan. Luten besloot op safe te spelen en enkel te ageren op de gronden a en c van artikel 106a lid $1 \mathrm{Fw}$, met succes: 'de rechter ging vrij snel mee in het onbehoorlijke bestuur'.

De gevorderde dwangsom van $€ 1000$ per dag bij overtreding van het bestuursverbod wordt afgewezen met de overweging in r.o. 3.21 dat de curator geen belang heeft bij een dwangsom:

35. Rb. Rotterdam 14 november 2018, ECLI:NL:RBROT:2018:9777, r.o. 3.18-3.19.

36. Rb. Rotterdam 14 november 2018, ECLI:NL:RBROT:2018:9777, r.o. 3.4-3.6.

37. Rb. Rotterdam 14 november 2018, ECLI:NL:RBROT:2018:9777, r.o. 3.19; Stb. 2016, 153, art. II.

38. Rb. Rotterdam 14 november 2018, ECLI:NL:RBROT:2018:9777, r.o. 3.16-3.17
'De eventueel te verbeuren dwangsom zal immers in mindering komen op het faillissementstekort en voor dit tekort is [gedaagde] op grond van dit vonnis al aansprakelijk. Bovendien zal het bestuursverbod op grond van de wet worden ingeschreven bij de KvK en zal [gedaagde] zich niet als bestuurder kunnen inschrijven en dit garandeert voor een groot deel de naleving van het bestuursverbod.'

Uit het laatste openbare faillissementsverslag blijkt dat de bestuurder in hoger beroep is gekomen tegen het vonnis en de curator is gedagvaard tegen 21 mei $2019 .{ }^{39}$ Voor Luten staan de onrechtmatige gedragingen van de betrokken bestuurder en de rechtmatigheid van het bestuursverbod vast. Zijn eventuele incidentele grieven zullen hoofdzakelijk gericht zijn op de motivering van de matiging van het bestuursverbod:

'Ik weet niet precies waarom nu een matiging is opgelegd. Kennelijk vond de rechtbank het te zwaar om vijf jaar op te leggen. Maar ik weet niet precies waarom dat te zwaar zou zijn. De bestuurder heeft niet voldaan aan zijn informatieplicht. Dat is bewezenverklaard. En als dat zo is, is dat volgens mij redelijk zwart-wit, en niet: je hebt een beetje niet voldaan aan je informatieplicht, dus leg ik je twee jaar op. Volgens mij is het zo dat als je niet voldoet aan de informatieplicht, het instrument erop gericht is dat je dan hangt voor het volledige bestuursverbod van vijf jaar. De rechtbank heeft op zichzelf wel de mogelijkheid om te matigen, maar dan vraag ik me af welke schending onvoldoende ernstig is om die vijf jaar niet op te leggen. Dat lees ik niet terug. Er wordt met een zin afgedaan, "dat het niet ernstig genoeg is", althans dat de feiten ertoe leiden dat er wordt gematigd.'

\subsection{Het verzoek van het civielrechtelijk bestuursverbod door de officier van justitie}

Het verdient vermelding dat het voor oplegging van een civielrechtelijk bestuursverbod niet van belang is of er sprake is van strafbare feiten, strafrechtelijke vervolging of een eerdere strafrechtelijke veroordeling wegens faillissementsfraude. Op vordering van het OM kan de strafrechter bij faillissementsfraude als bijkomende straf ook een strafrechtelijk beroepsverbod ex artikel 28 lid 1 Sr opleggen, dat een bestuursverbod kan behelzen. Als aan een verdachte eerder een civielrechtelijk bestuursverbod is opgelegd, kan de strafrechter daar bij de strafoplegging rekening mee houden. Volgens de wetgever heeft een civielrechtelijk bestuursverbod een belangrijke toegevoegde waarde om snel passende maatregelen te nemen tegen bestuurders die in een faillissement verwijtbaar hebben gehandeld. ${ }^{40}$ Deze beleidsdoelstelling impliceert dat het voor de hand ligt dat het OM eerst om een civielrechtelijk bestuursverbod verzoekt voordat een eventueel strafrechtelijk beroeps-

39. Openbaar faillissementsverslag rechtspersoon (ex art. 73A Fw), insolventienummer F.10/16/496, verslag van 22 februari 2019, par. 1.2., 7.5. en 9.3 .

40. MvT, p. 4. 
verbod wordt geëist. Dit zien wij ook terug in de rechtspraktijk.

Het OM heeft om twee civielrechtelijke bestuursverboden verzocht die werden toegewezen door respectievelijk de Rechtbank Midden-Nederland en de Rechtbank Amsterdam. In beide zaken werden de betrokken bestuurders op verzoek van het $\mathrm{OM}$ veroordeeld tot betaling aan de staat van een dwangsom van $€ 10.000$ voor elke overtreding van het bestuursverbod, met een maximum van $€ 100.000$. Vermeldenswaardig is dat de twee bestuursverboden zijn verzocht door een en dezelfde officier van justitie van het parket Zwolle.

\section{Civielrechtelijk bestuursverbod 4}

Het OM verzocht met succes de Rechtbank Midden-Nederland om de betrokken bestuurder op grond van artikel 106a lid 1 sub d Fw een civielrechtelijk bestuursverbod op te leggen voor de duur van vijf jaar. ${ }^{41}$ Het gaat in deze zaak dus om faillissementsrecidive (d-grond). Cruciaal in deze zaak is dat de rechtbank heeft vastgesteld dat de betrokken bestuurder geen verweerschrift heeft ingediend en niet naar de mondelinge behandeling is gekomen. Dat heeft tot gevolg dat de rechtbank ervan uit is gegaan dat het klopt dat betrokkene een persoonlijk verwijt kan worden gemaakt van de drie gefailleerde rechtspersonen waarvan betrokkene bestuurder was en die na de inwerkingtreding van de Wet civielrechtelijk bestuursverbod zijn uitgesproken, zoals uit het verzoek van het OM blijkt. ${ }^{42}$ De omstandigheid dat betrokkene in de afgelopen jaren als bestuurder en/of aandeelhouder betrokken is geweest bij 109 rechtspersonen, waarvan een groot deel is ontbonden en/of failliet is verklaard, evenals dat de curatoren in de drie faillissementen melding hebben gemaakt van vermoedelijke faillissementsfraude bij het fraudemeldpunt van de Belastingdienst waarbij steeds de administratie niet op orde was, kan de zaak verder hebben ingekleurd. ${ }^{43}$ De rechtbank gaat op deze punten echter niet in. Zij vormen immers geen noodzakelijke voorwaarden voor het toewijzen van het verzoek tot oplegging van het civielrechtelijk bestuursverbod.

\section{Civielrechtelijk bestuursverbod 5}

In een recente uitspraak heeft de Rechtbank Amsterdam op verzoek van het OM de bestuurder van onder meer de gefailleerde DM Holding B.V. een civielrechtelijk bestuursverbod opgelegd voor de duur van vijf jaar. Het OM motiveerde het verzoek aan de hand van zes faillissementen van rechtspersonen waarvan de betrokkene (middellijk) bestuurder is of was. De betrokkene zou ten aanzien van elk van deze afzonderlijke faillissementen zijn informatie- of medewerkingsplicht jegens de faillissementscurator hebben geschonden (art. 106a lid 1 sub c Fw). Daarnaast was volgens het OM sprake van faillisse-

\footnotetext{
41. Rb. Midden-Nederland 19 december 2018, ECLI:NL:RBMNE: 2018:6261.

42. Rb. Midden-Nederland 19 december 2018, ECLI:NL:RBMNE: 2018:6261, r.o. 2.4 .

43. Rb. Midden-Nederland 19 december 2018, ECLI:NL:RBMNE: 2018:6261, r.o. 2.1-2.3.
}

mentsrecidive (art. 106a lid 1 sub d Fw). ${ }^{44}$ De zaak spitst zich hoofdzakelijk toe op de schending van de informatie- en medewerkingsplicht jegens de curator in het faillissement van DM Holding B.V. (c-grond). In het openbare faillissementsverslag van DM Holding B.V. meldt curator I.C.J.C. van de Klundert dat de betrokken bestuurder zich doelbewust onbereikbaar houdt, niet verschijnt op verhoren en vervolgens in bewaring is gesteld in de Penitentiaire Inrichting te Vught waar hij is gehoord. ${ }^{45}$ De bestuurder zou geen administratie van de gefailleerde rechtspersonen hebben aangeleverd en bovendien aan de curator hebben verklaard dat er ook geen administratie is gevoerd. Betrokkene heeft in het geheel geen jaarrekeningen gedeponeerd. ${ }^{46} \mathrm{Nu}$ het voor Van de Klundert duidelijk was dat op de bestuurder waarschijnlijk niets verhaald kon worden, gelet op zijn privéfaillissement, heeft Van de Klundert afgezien van het aansprakelijk stellen van de bestuurder, hoewel er sprake is van onbehoorlijk bestuur. In het interview gaf Van de Klundert eveneens te kennen dat het uitsluitend vorderen van een bestuursverbod geen tak is van de curator. Daarnaast meldde Van de Klundert dat zij aan haar rechtmatigheidsonderzoek geen verder gevolg heeft gegeven nu de FIOD ook een strafrechtelijk onderzoek was gestart wegens vermoedens van faillissementsfraude bij een andere gefailleerde rechtspersoon, Grandoos Groothandel B.V., waarvan betrokkene ook bestuurder was. ${ }^{47}$

Van de Klundert heeft als het ware het stokje aan het OM overgedragen. $\mathrm{Zij}$ meldde in het openbare faillissementsverslag: 'De curator acht het echter niet opportuun om de bestuurder via de civiele weg aansprakelijk te stellen. Het is immers aannemelijk dat de bestuurder, gelet op zijn privé faillissement, niet over verhaalsmogelijkheden beschikt. Mogelijk volgt nog een strafrechtelijk vervolging. ${ }^{4} 88$

Vlak na het opheffen van het faillissement begin 2018 werd Van de Klundert benaderd door het OM:

'Ik kreeg een belletje van het OM. Ik had het idee dat het OM een taakstelling had om een aantal bestuursverboden op te leggen. Deze zaak lag voor de hand. Het OM was aan het onderzoeken of het dhr. [naam] een civielrechtelijk bestuursverbod kon opleggen en of ik bereid was mijn medewerking te verlenen door een verklaring af te geven en andere aanvullende documenten bovenop de faillissementsverslagen. Ik heb mijn schriftelijke verklaring gemaild.'

44. Rb. Amsterdam 24 januari 2019, ECLI:NL:RBAMS:2019:466, r.o. 2.1-2.2.

45. Openbaar faillissementsverslag rechtspersoon (ex art. 73A Fw), insolventienummer F.01/17/69, nr. 3, verslag van 14 februari 2018, zie p. 3 onder 'Toelichting'.

46. Openbaar faillissementsverslag rechtspersoon (ex art. 73A Fw), insolventienummer F.01/17/69, nr. 3, verslag van 14 februari 2018, par. 7.1-7.2.

47. Openbaar faillissementsverslag rechtspersoon (ex art. 73A Fw), insolventienummer F.01/17/69, nr. 3, verslag van 14 februari 2018, zie p. 3 onder 'Toelichting' en par. 7.1, 7.5 en 7.6.

48. Openbaar faillissementsverslag rechtspersoon (ex art. 73A Fw), insolventienummer F.01/17/69, nr. 3, verslag van 14 februari 2018, par. 7.1. 
Of de betrokken bestuurder is vervolgd door het OM nadat hij een civielrechtelijk bestuursverbod opgelegd had gekregen, wist Van de Klundert niet. Nu het civielrechtelijk bestuursverbod is toegewezen, lijkt een strafrechtelijke vervolging niet aannemelijk.

Het is interessant dat het OM hoofdzakelijk steunt op de verklaringen van Van de Klundert om aan te tonen dat betrokkene in ernstige mate zijn informatie- en medewerkingsplicht jegens de faillissementscurator heeft geschonden. ${ }^{49}$ Betrokkene voerde verweer en deed tevergeefs een beroep op het nemo tenetur-beginsel. In essentie komen de overwegingen van de rechtbank erop neer dat het civielrechtelijk bestuursverbod niet aangemerkt kan worden als een criminal charge in de zin van artikel 6 EVRM..$^{50}$ De gijzeling door de curator diende ertoe om van betrokkene inlichtingen te verkrijgen omtrent de staat van de faillissementsboedel, en levert geen strijd op met artikel 6 EVRM, aldus de rechtbank met verwijzing naar ECLI:NL:HR:2014:161. ${ }^{51}$ De omstandigheid dat betrokkene ondanks de gijzeling van de curator toegezegd heeft tot medewerking en informatieverschaffing, maar desondanks deze verplichting niet is nagekomen, leidde ertoe dat de rechtbank aan betrokkene een bestuursverbod zoals bedoeld in artikel 106a lid 1 sub c Fw voor de duur van vijf jaren heeft opgelegd. ${ }^{52}$ Voor het opleggen van een civielrechtelijk bestuursverbod vindt de rechtbank het beroep van het OM op de c-grond met betrekking tot enkel het faillissement van DM Holding B.V. voldoende. Daarom laat de rechtbank het door het OM gedane beroep op de c-grond ten aanzien van het faillissement van de andere rechtspersonen en de d-grond voor het overige onbesproken..$^{53}$

\subsection{Bespiegelingen}

\section{Beter motiveren van (verstek)vonnissen}

Van de onderzochte zaken hebben wij twee vonnissen besproken die zijn gewezen zonder dat de betrokken bestuurder aanwezig was ter zitting en verweer heeft gevoerd. ${ }^{54}$ Deze twee vonnissen kenmerken zich door zeer summiere

49. Rb. Amsterdam 24 januari 2019, ECLI:NL:RBAMS:2019:466, r.o. 2.4-2.5.

50. Rb. Amsterdam 24 januari 2019, ECLI:NL:RBAMS:2019:466, r.o. 3.10.1.

51. Rb. Amsterdam 24 januari 2019, ECLI:NL:RBAMS:2019:466, r.o. 3.11 .

52. Interessant is dat de Rechtbank Amsterdam strikt onderscheid maakt tussen een eventueel strafproces en de civielrechtelijke procedure: 'De keuze om wegens 'strafrechtelijke onzekerheid' te zwijgen jegens de civielrechtelijke wederpartij (de curator) betekent niet dat die wederpartij geen beroep kan doen op een civielrechtelijke norm (art. 105 lid 1 (oud) Fw) die door dat zwijgen wordt geschonden. De consequentie daarvan is dat ook die schending kan worden ingeroepen in het kader van een op de c-grond gevraagd bestuursverbod, waarbij het niet uitmaakt of de curator of het OM de verzoekende partij is', zie: Rb. Amsterdam 24 januari 2019 , ECLI:NL:RBAMS:2019:466, r.o. 3.11.1.

53. Rb. Amsterdam 24 januari 2019, ECLI:NL:RBAMS:2019:466, r.o. 3.13 en 2.2 .

54. Rb. Den Haag 13 juni 2018, ECLI:NL:RBDHA:2018:8801 en Rb. Midden-Nederland 19 december 2018, ECLI:NL:RBMNE:2018:6261; tegen een verstekvonnis dient de bestuurder eerst in verzet te komen. motivering. Een van de curatoren merkte op dat de summiere motivering mogelijk te wijten is aan het feit dat rechters verstekvonnissen eerder terughoudend motiveren dan uitgebreid. Dit klemt nu de consequenties van een civielrechtelijk bestuursverbod zeer ernstig kunnen zijn voor de betrokken bestuurder. Daarnaast staat tegen een bestuursverbod hoger beroep (en cassatie) open. ${ }^{55}$ Adequate motivering van het vonnis is van belang om in een eventueel hoger beroep gerichte grieven te kunnen formuleren en (vastgestelde) feiten te kunnen aanvullen dan wel te ontkrachten. Ook verstekvonnissen dienen voldoende te worden gemotiveerd, zodat partijen kunnen inschatten of er redenen zijn om verzet te doen. ${ }^{56}$

\section{Het civielrechtelijk bestuursverbod als hoofdvordering}

In de memorie van toelichting wordt de verwachting uitgesproken dat een vordering van de curator tot oplegging van een civielrechtelijk bestuursverbod in de praktijk heel vaak zal samengaan met een (neven)vordering tot het vaststellen van de bestuurdersaansprakelijkheid ex artikel 2:138/2:248 BW. ${ }^{57}$ De geïnterviewde curatoren zien het civielrechtelijk bestuursverbod - in zijn algemeenheid - in het kader van een bestuurdersaansprakelijkheidsprocedure als nevenvordering. In de eerder beschreven zaken dient de vordering tot oplegging van het bestuursverbod echter - met en dankzij de medewerking van de Belastingdienst - bij wijze van experiment als een hoofdvordering voor beide curatoren te worden beschouwd. Voor het opleggen van een bestuursverbod is de vaststelling van bestuurdersaansprakelijkheid geen vereiste, maar strekt het duidelijk tot voordeel. In beide zaken bleek verder dat de rechter vrij snel tot het bestuurdersaansprakelijkheidsoordeel was gekomen om vervolgens de stap naar het civielrechtelijk bestuursverbod te zetten. Een interessant fragment uit het interview met Luten:

'Er is onduidelijkheid over het aanvoeren van de a-grond terwijl bestuurdersaansprakelijkheid nog niet vaststaat. Ik heb de bestuurdersaansprakelijkheid voorwaardelijk aangevoerd in de zaak om te kijken of dat kan, en de rechtbank heeft gezegd: "het kan”. Ik heb natuurlijk ook een andere grond aangevoerd waardoor het bestuursverbod gelijk kon worden opgelegd. Daar deed de rechtbank dus niet moeilijk over. Ik denk niet dat zij daar heel lang bij stil

55. MvT, p. 14.

56. Uit onderzoeken blijkt dat natuurlijke personen, zo ook bestuurders, een juridische procedure waarbij zij als persoon of als professional worden bekritiseerd als zeer traumatisch kunnen ervaren (Pham 2017, p. 30; E.R. Carrier e.a., High physician concern about malpractice risk predicts more aggressive diagnostic testing in office-based practice, Health Affairs 2013 (32), p. 1389; E.R. Carrier e.a., Physicians' fears of malpractice lawsuits are not assuaged by tort reforms, Health Affairs 2010 (29), p. 1591; C. Palacio, Psychological effects of poor outcome and professional liability actions on physicians, Southern Medical Journal 2008 (101), p. 1032-1043; C.A. Martin e.a., Physicians' psychological reactions to malpractice litigation, Southern Medical Journal 1991 (84), p. 1300-1304). Een belangrijke voorwaarde voor een bestuurder om een dergelijk trauma te verwerken, is de mogelijkheid om zich te verdedigen en uitleg te bieden (Pham 2017, p. 30; Martin e.a. 1991, p. 1308).

57. MvT, p. 14 
heeft gestaan, maar in de rechtspraktijk zijn er wel vragen over.'

\section{Financiële drempel voor de curator}

In de literatuur wordt angenomen dat de kosten van een procedure een hoge drempel vormen voor de curator om een civielrechtelijk bestuursverbod te vorderen. ${ }^{58}$ De praktijkvoorbeelden bevestigen deze aanname. Alhoewel curatoren een beroep kunnen doen op de Garantstellingsregeling curatoren 2012 om de kosten van bepaalde juridische acties bij wijze van voorschot vergoed te krijgen, waren de curatoren die wij spraken vrij somber over de toepassing van de regeling in gevallen waarbij de verhaalsmogelijkheden miniem zijn. De screeningsautoriteit Justis beoordeelt een dergelijke aanvraag op basis van de schulden van de crediteuren, de waarde van de boedel en welke personen de curator wil aanspreken en op welke rechtsgronden. Eveneens beperkt Justis de rechtsgronden en daarmee de mogelijke juridische acties tot artikel 2:9 BW, artikel 2:138/2:248 BW, artikel 2:149/2:259 BW en artikel 42, 43 en $47 \mathrm{Fw}^{.99}$ Het vorderen van een civielrechtelijk bestuursverbod zonder een (hoofd)vordering die valt binnen de genoemde categorieën, komt dan ook niet in aanmerking voor de garantstellingsregeling. ${ }^{60}$

De omstandigheid dat zowel de curator als de rechter-commissaris vermoedde dat er sprake was van malafide gedragingen én de curator medewerking kreeg van schuldeisers om een procedure te starten tegen de betrokken bestuurder(s), maakte dat de curatoren, ondanks het ontbreken van verhaalsmogelijkheden, toch hebben besloten over te gaan tot het vorderen van een civielrechtelijk bestuursverbod. Opmerkelijk is dat in de twee praktijkvoorbeelden (zie par. 3.2) de betrokken curatoren zelfs werden aangespoord door de schuldeisers van de gefailleerde vennootschappen. In het bijzonder zag de Belastingdienst heil in het nieuwe instrumentarium. De curatoren geven wel een belangrijke waarschuwing. De Belastingdienst was bereid een kleine financiële bijdrage aan de boedel te leveren, enkel om medewerking te verlenen aan een aantal test cases. Van Apeldoorn is ervan overtuigd dat de Belastingdienst dit niet zal blijven doen. Wil de wetgever dat curatoren effectief gebruikmaken van het civielrechtelijk bestuursverbod, dan zal de wetgever ook een structurele oplossing moeten bieden voor de kosten waarmee curatoren geconfronteerd worden. Immers, curatoren zien het behartigen van de belangen van de boedel toch als hun hoofdtaak:

58. Zie o.a. Keijzer \& Lennarts 2014, p. 133-134 en 153; R. van Galen, Fraudebestrijding en bestuursverbod, Ondernemingsrecht 2016/116, afl. 16, p. 577-578; H.J. Vetter, Een dode letter?, O\&F 2018, afl. 3, p. 3-4.

59. Zie daarvoor het document Vragenlijst 'Nieuw verzoek' Garantstellingsregeling curatoren 2012, onder nr. 5, te raadplegen op www.justis.nl/ producten/gsr/beroep-doen-op-garantstellingsregeling/index.aspx.

60. Een oplossing is het verruimen van de reikwijdte van de Garantstellingsregeling curatoren 2012 tot inspanningen van de curator die gericht zijn op de aanpak van faillissementsfraude die niet tevens tot verhaal leiden, zoals Keijzer en Lennarts al eerder opperden, zie: Keijzer \& Lennarts 2014, p. 153.
'Als curator behartig je natuurlijk de belangen van de boedel, en de boedel is er in beginsel niet bij gebaat dat er een bestuursverbod wordt opgelegd. Daar is de maatschappij bij gebaat, maar de boedel heeft daar niet zo veel aan. Ik zie namelijk niet in waarom schuldeisers blij zouden zijn als je een bestuursverbod vordert, anders dan dat zij misschien vinden dat dat nodig is', aldus Luten.

\section{Kostenefficiëntie}

Vanuit de kostenefficiëntie is het interessant te zien hoe Van de Klundert grenzen legt aan haar bevoegdheden als curator en een oproep doet aan het Openbaar Ministerie om op te treden tegen de betrokken bestuurder. Dit praktijkvoorbeeld biedt een aansprekend handelingsperspectief aan een curator die geconfronteerd wordt met geen of nauwelijks verhaalsmogelijkheden, maar waarbij wel sterke vermoedens spelen dat zich malafide praktijken hebben voorgedaan. De curator kan het $\mathrm{OM}$ aansporen een civielrechtelijk bestuursverbod te verzoeken, althans alle medewerking aan het $\mathrm{OM}$ te verlenen. Hiermee verschuift de curator tevens het risico en de kosten van het voeren van de procedure naar het OM.

\section{Reflectie: tweede kans en stigma}

\subsection{De beleidsdoelstelling van de wetgever en de rechtspraktijk}

Wij begonnen deze bijdrage met de beleidsdoelstelling van de wetgever om de samenleving te beschermen tegen enerzijds frauduleuze bestuurders die rechtspersonen met beperkte aansprakelijkheid willen misbruiken en anderzijds onkundige maar bonafide bestuurders die niet verantwoordelijk kunnen omgaan met het voorrecht van beperkte aansprakelijkheid. Ons onderzoek naar de eerste ervaringen met het civielrechtelijk bestuursverbod laat zien dat het instrumentarium door curatoren $^{61}$ en het OM niet lichtzinnig wordt toegepast.

Voor willekeurig of ongebreideld optreden van de curator hoeft niet te worden gevreesd. In de belangenafweging die de curator - onder toezicht van de rechter-commissaris - makt tussen de kosten voor de schuldeisers die met de vordering tot oplegging van het civielrechtelijk bestuursverbod zijn gemoeid en het publieke belang dat gediend wordt met deze vordering, zal de curator het belang van de gezamenlijke schuldeisers vooropstellen. Het publieke belang en het belang van schuldeisers - dat niet enkel bestaat uit boedelmaximalisatie, maar ook bijvoorbeeld uit genoegdoening, het willen stoppen of zelfs straffen van de betrokken bestuurder - kunnen samenvallen. Kennelijk vormden de zeer ernstige gedragingen van de betrokken bestuurders een belangrijke prikkel voor de curator, onder druk van schuldeisers, om een civielrechtelijk bestuursverbod te vorderen.

Voor het OM biedt het civielrechtelijk bestuursverbod ten opzichte van het strafrechtelijke beroepsverbod een duidelijke

61. MvT, p. 10 en 15. 
verlichting van bewijs. ${ }^{62}$ In de twee praktijkvoorbeelden waarbij het Openbaar Ministerie om een civielrechtelijk bestuursverbod heeft verzocht, lijken rechters een strikte scheiding aan te brengen tussen een civiele procedure en een strafvervolging. Wij begrijpen de technisch-juridische uitleg van de Rechtbank Amsterdam, ${ }^{63}$ maar op basis van de Europese 'tweede kans'doelstelling en de theorie over labeling is deze uitleg problematisch. Wij lichten dit toe in de paragrafen 4.2 en 4.3 . Kort gezegd zouden de wetgever en de rechter zich onzes inziens bewust moeten zijn van de sociale consequenties die volgen voor de betrokken bestuurders wanneer de civielrechtelijke bestuursverboden - ongeacht of er onbewezen strafrechtelijke gedragingen aan ten grondslag liggen - door de KvK openbaar worden gemaakt.

\subsection{Het civielrechtelijk bestuursverbod in het licht van de Europese 'tweede kans'-doelstelling}

Het civielrechtelijk bestuursverbod sluit volgens de wetgever goed aan bij de visie van de Europese Commissie (EC). ${ }^{64}$ Daarbij verwijst de wetgever naar een visiedocument van de EC uit 2012 waarin een nieuwe aanpak van insolventie wordt bepleit, met een scherper onderscheid tussen bonafide en malafide ondernemers. ${ }^{65}$ De EC benadrukt met haar 'tweede kans'-doelstelling het risico dat eerlijke ondernemers last kunnen hebben van het sociale stigma dat met een faillissement gepaard gaat. ${ }^{66}$ Eerder, in 2007 , benadrukt de EC dat een faillissement in de publieke opinie vaak in verband wordt gebracht met persoonlijk onvermogen of fraude van de ondernemer. Een faillissement wordt vaak gezien als een strafbare handeling, ongeacht de oorzaak ervan. ${ }^{67}$ Daarbij constateert de EC dat in veel landen het faillissementsrecht geen onderscheid maakt tussen enerzijds een faillissement dat frauduleus is of aan onverantwoordelijk gedrag te wijten is, en anderzijds een faillissement waarbij de eigenaar of bedrijfsleider geen duidelijke schuld ten laste kan worden gelegd, en waarbij deze dus eerlijk en correct heeft gehandeld. ${ }^{68}$ De EC gaat uit van de begrippen 'eigenaar' en 'bedrijfsleider'. De EC concludeert dan ook dat erkend moet worden 'dat een ondernemer weliswaar kan mislukken, maar vervolgens ook opnieuw kan starten' ${ }^{69}$

62. Vergelijk Rb. Amsterdam 12 december 2018, ECLI:NL:RBAMS: 2018:8921, r.o. 8.1 en 8.3.

63. Rb. Amsterdam 24 januari 2019, ECLI:NL:RBAMS:2019:466, r.o. 3.10 e.v.

64. MvT, p. 2.

65. Mededeling van de Commissie aan het Europees Parlement, de Raad en het Europees Economisch en Sociaal Comité, Een nieuwe aanpak van faillissementen en insolventie, $\operatorname{COM}(2012) 742$, p. 6. Voor inzicht in het belang van het onderscheid tussen bonafide en malafide bestuurders, zie ook: Pham 2017, p. 5-7 en 161-162.

66. Zie ook: T. Tajti, Bankruptcy stigma and the second chance policy: the impact of bankruptcy stigma on business restructurings in China, Europe and the United States, China-EU Law Journal 2018, vol. 6, afl. 1-2, p. 5-6.

67. Mededeling van de Commissie aan de Raad, het Europees Parlement, het Europees Economisch en Sociaal Comité en het Comité van de Regio's, Het stigma van een bedrijfsfaillissement overwinnen - een beleid voor een tweede kans, COM(2007) 584, p. 7 (hierna: Mededeling EC 2007).

68. Mededeling EC 2007, p. 7.

69. Mededeling EC 2007, p. 9.
Volgens de EC is het bekend dat opnieuw gestarte ondernemers het niet slechter doen dan anderen. ${ }^{70}$ Desondanks zijn afnemers en kredietgevers huiverig om bij deze ondernemers bestellingen te plaatsen of te investeren. Van de geïnterviewde EU-respondenten zegt

'79\% van de EU-burgers (...) weliswaar dat zij ondernemers die voorheen mislukt zijn een tweede kans zouden willen geven. Maar in de praktijk wil deze mening nog wel eens veranderen. $47 \%$ van de Europeanen zou slechts met tegenzin een order bij een eerder failliet gegaan bedrijf plaatsen. $51 \%$ zou nooit in bedrijven die in financiële moeilijkheden verkeren investeren'. ${ }^{71}$

De EC heeft de 'tweede kans'-doelstelling in 2016 uitgewerkt in een voorstel voor een richtlijn van het Europees Parlement en de Raad betreffende preventieve herstructureringsstelsels, een tweede kans en maatregelen ter verhoging van de efficiëntie van herstructurerings-, insolventie- en kwijtingsprocedures, en tot wijziging van Richtlijn 2012/30/EU (hierna: voorgestelde insolventierichtlijn). ${ }^{72}$ Een belangrijke doelstelling van de voorgestelde insolventierichtlijn is het voorkomen 'dat ondernemers en bedrijfsleiders gestigmatiseerd worden wanneer hun bonafide zakelijke projecten mislukken' ${ }^{73}$ Dit ontmoedigt ondernemerschap. Deze 'tweede kans'-filosofie wordt ook gerelateerd aan het beroepsverbod voor natuurlijke personen: 'Een echte tweede kans impliceert ook dat de duur van beroepsverboden voor bonafide ondernemers met een overmatige schuldenlast wordt beperkt zodat deze mensen na een redelijke termijn weer actief kunnen worden als ondernemer. ${ }^{74}$ De term 'beroepsverbod' wordt niet gedefinieerd. Ook wordt geen onderscheid gemaakt tussen een strafrechtelijk beroepsverbod of een civielrechtelijk beroepsverbod. Zo wordt in de voorgestelde insolventierichtlijn bijvoorbeeld overwogen dat een beroepsverbod langer of voor onbepaalde tijd mag gelden in gevallen waarin de ondernemer voor criminele activiteiten is veroordeeld. ${ }^{75}$

In het licht van deze gedachten van de Europese Commissie bezien kan het civielrechtelijk bestuursverbod een instrument zijn dat het sociale stigma dat met een faillissement gepaard gaat, versterkt. Lichtzinnig gebruik van het instrument door

70. Mededeling EC 2007, p. 4.

71. Mededeling EC 2007, p. 4. De EC verwijst naar het Flash Eurobarometer (192) rapport 'Entrepreneurship Survey of the EU (25 Member States), United States, Iceland and Norway. Analytical Report' van 2007, p. $89-94$.

72. $\operatorname{COM}(2016)$ 723. Zie het wetgevingstraject op https://eurlex.europa.eu/procedure/NL/ 2016_359\#2019-03-28_ADP_R1_POS_byEP.

73. Voorgestelde insolventierichtlijn, p. 7 .

74. Voorgestelde insolventierichtlijn, p. 16. Over de duur van beroepsverboden voor ondernemers met een overmatige schuldenlast, zie art. 21 van de voorgestelde insolventierichtlijn, p. 56. Een ondernemer met een overmatige schuldenlast wordt in art. 2 lid 13 van de voorgestelde insolventierichtlijn, p. 44, gedefinieerd als 'een natuurlijke persoon die een handels-, bedrijfs-, ambachts- of beroepsactiviteit uitoefent en die anders dan tijdelijk niet in staat is om op de vervaldatum zijn schulden te betalen'.

75. Overweging 38 van de voorgestelde insolventierichtlijn, p. 39. 
de curator of het OM kan tot gevolg hebben dat een onkundige maar bonafide bestuurder last krijgt en blijft houden van een sociaal stigma. De gegevens van de betrokkene zijn immers voor de duur van het bestuursverbod te raadplegen op de website van de $\mathrm{KvK}$. Het is denkbaar dat deze gegevens door een web crawler worden gekopieerd en belanden op buitenlandse websites waarvan de beheerder onbereikbaar blijft. ${ }^{76}$ Volgens de wetgever is een volledig openbare registratie van het civielrechtelijk bestuursverbod proportioneel, omdat het bestuursverbod slechts raadpleegbaar zou zijn voor de duur - maximaal vijf jaar - waarvoor het is opgelegd vanaf de dag dat de uitspraak onherroepelijk is geworden. ${ }^{77}$ De openbare registratie van het civielrechtelijk bestuursverbod is volgens hem gerechtvaardigd vanwege zwaarwegende algemene belangen, waaronder 'transparantie, effectieve handhaving van het bestuursverbod, bestrijding van faillissementsfraude en de katvanger-problematiek, de bescherming van rechten en vrijheden van anderen en de eerlijkheid in het handelsverkeer. ${ }^{78}$

Eerder is in de literatuur over het conceptwetsvoorstel al gewezen op het stigmatiserende effect dat opname van civielrechtelijke bestuursverboden in een openbaar register heeft. Zo wijzen Boswijk en Vreede onder meer op de mogelijkheid van banken om natuurlijke personen kredieten te onthouden op basis van het openbare register, omdat de gedachte kan bestaan dat personen die op een dergelijke openbare lijst staan mogelijk fraudeurs zijn. Het openbare register kan dan worden beschouwd als een vorm van naming and shaming die de reputatie en eer van de betrokkene antast. ${ }^{79}$ Ook Philips wijst erop dat de publicatie van persoonsgegevens een 'sanctie' op zich is die veel verder reikt dan het enkel blokkeren van toekomstig bestuurderschap. Gelet op de sociale consequenties voor betrokkene - met een zoekactie op Google kan eenieder zijn naam en geboortedatum vinden - stelt Philips dat een civielrechtelijk 'bestuursverbod de facto [zou] kunnen leiden tot een diskwalificatie voor meer dan alleen het bestuur van een rechtspersoon'. ${ }^{80}$

Over het karakter van het civielrechtelijk bestuursverbod - strafrechtelijk of civielrechtelijk - is in de literatuur over het concept-wetsvoorstel en de consultatiereacties de nodige aan-

76. De persoonsgegevens van betrokkenen in het overzicht van de civielrechtelijke bestuursverboden op de website van de KvK zijn door Google geïndexeerd (www.kvk.nl/over-kvk/overzicht-civielrechtelijkbestuursverbod/). Het zou raadzaam zijn als de KvK deze indexering tegengaat. Zie ook voetnoot 3 .

77. Namen van de rechtspersonen moeten na afloop van het civielrechtelijk bestuursverbod niet meer zichtbaar zijn in de vonnissen en andere openbare documenten, zoals faillissementsverslagen. Anders wordt het mogelijk om alsnog na afloop van het bestuursverbod te achterhalen welke personen de bestuurders waren van de gefailleerde rechtspersonen.

78. MvT, p. 6-7; Kamerstukken I 2015/16, 34011, B, p. 6.

79. R.J. Boswijk \& N. Vreede, Het wetsvoorstel Civielrechtelijk Bestuursverbod: de Kamer wordt beperkt ingelicht over de inlichtingenplicht, TvI 2013/27, par. 2.2; D.R. Doorenbos, Naming \& shaming (oratie Nijmegen), Deventer: Kluwer 2007, p. 26-27.

80. Philips 2013, p. 117. Zie ook: H. Koster, Het Nederlandse handelsregister: openbaarheid, transparantie en privacy, WPNR 2017/7169, p. $875-876$. dacht besteed. ${ }^{81}$ De wetgever en de Rechtbank Amsterdam stellen dat het civielrechtelijk bestuursverbod niet strafrechtelijk van aard is. ${ }^{82}$ Dat neemt niet weg dat er wel degelijk een discrepantie kan bestaan tussen de juridische en de reële werkelijkheid. In de reële wereld associeert onzes inziens de gemiddelde Nederlander het opgelegde civielrechtelijk bestuursverbod wel met bestraffing wegens bedrijfsmislukking en/of strafrechtelijke gedragingen bij faillissement. ${ }^{83}$ Deze reële associatie is in lijn met de eerdergenoemde opvatting van de EC dat een faillissement in de Europese publieke opinie vaak geldt als een strafbare handeling, ongeacht de oorzaak ervan. ${ }^{84}$ Ook de minister van Veiligheid en Justitie spreekt tijdens de plenaire behandeling van de wet in termen van 'straf wanneer hij antwoord geeft op de vraag of het feit dat een civielrechtelijk bestuursverbod is opgelegd, ook na het einde van het bestuursverbod zichtbaar moet blijven:

'Ik vind dat een vrij principiële vraag. Als het zichtbaar blijft, wordt het in feite een levenslang bestuursverbod, omdat de facto iedereen dan kan weten dat je ooit een bestuursverbod hebt gekregen. Het uitgangspunt van de wet is dat registratie plaatsvindt voor de duur van het verbod. Daarna volgt schrapping van het verbod uit het Handelsregister. De straf is dan voorbij. Als het zichtbaar zou zijn, zou ik dat niet proportioneel vinden ten opzichte van de toepassing van de toch vrij heftige straf. ${ }^{95}$

Maar tegelijkertijd haalt de minister zijn schouders op als namen van personen met een civielrechtelijk bestuursverbod mogelijk permanent op het internet vindbaar zijn:

'Het spreekt voor zich dat het register zeer zorgvuldig zal worden ingericht, maar ik kan er weinig aan doen dat mensen in het digitale domein informatie uit het register beschikbaar stellen en houden. Dat is in feite bij elk regis-

81. Zie: Doorenbos 2014, par. 4; Keijzer 2013, par. 4.2; Boswijk \& Vreede 2013, par. 3; consultatiereactie Loyens \& Loeff, p. 2; consultatiereactie VNO-NCW en MKB-Nederland, p. 3; consultatiereactie Gecombineerde Commissie Vennootschapsrecht van de Nederlandse Orde van Advocaten en de Koninklijke Notariële beroepsorganisatie, nr. 2.2. Over het punitieve of civiele karakter van het Engelse civielrechtelijk bestuursverbod, zie: Neekilappillai 2014, par. 3.1. Voor een meer recente bijdrage hierover, zie: M.C.E. Peels, Wetsvoorstel Civielrechtelijk Bestuursverbod en nemo tenetur: wikken en wegen, TvI 2015/4, p. 26-27.

82. MvT, p. 9-10; Rb. Amsterdam 24 januari 2019, ECLI:NL:RBAMS: 2019:466, r.o. 3.10.1.

83. De gronden voor de oplegging van een strafrechtelijk beroepsverbod komen deels overeen met de gronden voor de oplegging van het civielrechtelijk bestuursverbod. Zo wijst Reker op de bankbreukdelicten in art. 343 aanhef sub 2 en $3 \mathrm{Sr}$ jo. art. $349 \mathrm{Sr}$ die vergelijkbaar zijn met paulianeuze gedragingen in art. 106a lid 1 sub b Fw en art. 194 lid $1 \mathrm{Sr}$ jo. art. 194 lid $3 \mathrm{Sr}$ met het niet meewerken met de curator zoals is opgenomen in art. 106a lid 1 sub c Fw, zie: T. Reker, Het gewijzigde wetsvoorstel civielrechtelijk bestuursverbod, TvI 2015/46, p. 320. De minister van Veiligheid en Justitie stelt dan ook dat 'Het Openbaar Ministerie [...] beide instrumenten [kan] inzetten en [...] zich bij de keuze [zal] laten leiden door de vraag wat specifiek in de bepaalde situatie nodig is en wat het effectiefste is om op te treden tegen fraudeurs', zie: Handelingen II 2014/15, nr. 97, item 6, p. 18.

84. Mededeling EC 2007, p. 7.

85. Handelingen II 2014/15, nr. 97, item 6, p. 16. 
ter denkbaar. Bij alle registers kan dat al plaatsvinden. (...) Een van die mogelijkheden is natuurlijk het doen van een verwijderingsverzoek bij social media of zoekmachines als iemand hier na afloop van een bestuursverbod nog last van heeft. Ik heb de indruk dat dit ook steeds bekender wordt. Ik merk op dat in Europees verband in het kader van de Dataprotectierichtlijn uitgebreid over dit fenomeen wordt gesproken.' 86

Als zelfs de minister van Veiligheid en Justitie het civielrechtelijk bestuursverbod associeert met het negatieve label 'straf, dan lijkt het ons goed denkbaar dat de gemiddelde Nederlander deze associatie ook makkt. Door de publicatie van het civielrechtelijk bestuursverbod kleeft aan de betrokkene een negatief label. Dit negatieve label belemmert de betrokkene zeer waarschijnlijk om gedurende zijn bestuursverbod handel te drijven als natuurlijke persoon of na afloop van zijn bestuursverbod weer bestuurder van een rechtspersoon te worden. Andere negatieve sociale consequenties door de openbaarmaking van het civielrechtelijk bestuursverbod, zoals eerder geschetst, zijn te voorzien. ${ }^{87}$ De sociale consequenties van de openbaarmaking van dit negatieve label - de betrokkene staat op een publiek toegankelijke lijst met fraudeurs en wanbestuurders - worden onzes inziens onvoldoende erkend door de wetgever. De wetgever laat na een zelfstandige rechtvaardiging te bieden voor het publiek labelen van (huidige en toekomstige) bestuurders die een civielrechtelijk bestuursverbod opgelegd krijgen.

\subsection{Publicatie van een civielrechtelijk bestuursverbod vraagt om zelfstandige rechtvaardiging}

Wanneer een bestuurder een civielrechtelijk bestuursverbod opgelegd krijgt, zal dit negatieve label aan hem kleven. In de ogen van de samenleving wordt de bestuurder geassocieerd met bestraffing wegens bedrijfsmislukking en/of strafrechtelijke gedragingen bij faillissement. In de sociologische literatuur wordt daarom gesteld dat labeling een stigmatiserende werking heeft en dat negatieve stigma's om rechtvaardiging vragen. ${ }^{88}$ De mate van stigmatisering van een specifiek individu hangt af van de mate waarin het label dat aan dat individu is gekoppeld, zichtbaar en herkenbaar is voor anderen. De negatieve reacties op dit label zijn noodzakelijk voor stigmatisering. Deze reacties maken dat stigmatisering begrepen kan worden als een last voor de betrokkene: stigmatisering leidt tot reputatieverlies, discriminatie en benadeling. Het gestigmatiseerde individu wordt vervreemd en uitgesloten van activiteiten en kansen die toegankelijk zijn voor niet-gestigmatiseerde personen. ${ }^{89}$ Daarom wil de EC het sociale stigma dat rust op het faillissement verminderen met haar 'tweede kans'regels in de voorgestelde insolventierichtlijn.

86. Handelingen II 2014/15, nr. 97, item 6, p. 19.

87. Boswijk \& Vreede 2013, par. 2.2; Doorenbos 2007, p. 26-27; Philips 2013, p. 117.

88. K. Hadjimatheou, Criminal Labelling, Publicity, and Punishment, Law and Philosophy 2016, vol. 35, afl. 6, p. 567-593.

89. Hadjimatheou 2016, p. 572; B.G. Link \& J.C. Phelan, Conceptualising Stigma, Annual Review of Sociology 2001, vol. 27, p. 363-385.
Publieke labeling - de openbare registratie - is geen noodzakelijk onderdeel van het civielrechtelijk bestuursverbod, terwijl het wel een noodzakelijke voorwaarde vormt voor stigmatisering. ${ }^{90}$ De wetgever zou onzes inziens moeten erkennen dat de sociale nadelen voor een betrokkene met een gepubliceerd civielrechtelijk bestuursverbod verdergaan dan alleen het ontnemen van zijn voorrecht om te ondernemen met beperkte aansprakelijkheid. De publicatie van een civielrechtelijk bestuursverbod beschouwen wij als een vorm van straf die zelfstandig gelegitimeerd dient te worden. Voor zover de wetgever meent dat de publicatie van opgelegde civielrechtelijke bestuursverboden een proportionele maatregel is, omdat met de openbaarmaking enig punitief oogmerk ontbreekt, dan wijzen wij erop dat ook 'niet-punitieve' reacties van anderen zoals (voormalige of toekomstige) handelspartners, wel degelijk als punitief kunnen worden beschouwd. Ook in het geval dat eventuele (voormalige of toekomstige) handelspartners geconfronteerd worden met het publieke label van de betrokken bestuurder, zonder dat zij bewust de bestuurder willen straffen, is het zeer aannemelijk dat zij in hun manier van interactie de betrokken bestuurder uitsluiten van sociale activiteiten en voordelen. ${ }^{91}$ Deze 'niet-punitieve' gedragingen ontstaan doordat handelspartners zich zeer ongemakkelijk voelen bij en bang zijn voor wat anderen zouden denken indien zij zich zouden inlaten met een gestigmatiseerde persoon. Deze 'nietpunitieve' reacties voegen leed toe aan de gestigmatiseerde. ${ }^{92}$ Dit leed wordt vermenigvuldigd naarmate meer anderen op vergelijkbare manieren reageren. De wetgever dient - gelet op deze sociale consequenties en het stigma dat in het algemeen rust op faillissement - beter te motiveren waarom het gerechtvaardigd is om (huidige en toekomstige) bestuurders publiekelijk te labelen met een civielrechtelijk bestuursverbod.

\section{Aanbevelingen}

Het onderzoek naar de eerste ervaringen met het civielrechtelijk bestuursverbod in de praktijk laat zien dat curatoren en het $\mathrm{OM}$ het instrument niet lichtzinnig gebruiken. Het lijkt erop dat tot nu toe enkel bestuurders die zich hebben ingelaten met malafide praktijken zijn getroffen door een civielrechtelijk bestuursverbod. Dit neemt niet weg dat de curator, de rechter-commissaris, het $\mathrm{OM}$ en de rechter waakzaam moeten blijven om onkundige maar bonafide bestuurders niet te treffen met een civielrechtelijk bestuursverbod vanwege het stigma dat door de publicatie hieraan kleeft. De ruimte om de onkundige maar bonafide bestuurder te treffen, biedt artikel 106a lid 1 Fw namelijk wel.

Wij constateren dat de Nederlandse wetgever onvoldoende oog heeft gehad voor de sociale nadelen die gepaard gaan met de publicatie van een civielrechtelijk bestuursverbod. De wet-

90. Hadjimatheou 2016, p. 569.

91. D. Markel \& C. Flanders, Bentham on Stilts: The Bare Relevance of Subjectivity to Retributive Justice, California Law Review 2010, vol. 98, afl. 3; D. Gray, Punishment as Suffering, Vanderbilt Law Review 2010, vol. 63, afl. 6, p. 1653

92. Hadjimatheou 2016, p. 582. 
gever zou zich nadrukkelijk moeten afvragen of publieke labeling - de automatische openbaarmaking - een onderdeel moet zijn van het civielrechtelijk bestuursverbod. Indien automatische openbaarmaking onderdeel moet zijn van het civielrechtelijk bestuursverbod, dan dient de wetgever hiervoor een zelfstandige rechtvaardigingsgrond te bieden. In de huidige situatie moet de rechtbank krachtens artikel 106b lid $3 \mathrm{Fw}$ de onherroepelijke uitspraak waarin een bestuursverbod is opgelegd aan de KvK aanbieden, waarna de KvK deze voor de duur van het civielrechtelijk bestuursverbod publiceert. We bevelen de wetgever aan om bij de evaluatie van de Wet civielrechtelijk bestuursverbod in 2021 te heroverwegen of aan de rechter een discretionaire bevoegdheid moet worden geboden om op grond van zwaarwegende maatschappelijke belangen te besluiten dat het opgelegde civielrechtelijk bestuursverbod openbaar geregistreerd wordt bij de KvK. ${ }^{93}$ De rechter kan vervolgens in zijn vonnis maatwerk bieden en motiveren waarom openbaarmaking van een civielrechtelijk bestuursverbod in een bepaald geval gerechtvaardigd is ondanks de sociale gevolgen voor de betrokkene. Deze principiële discussie dient onzes inziens door de wetgever gevoerd te worden. ${ }^{94}$

Mocht de wetgever toch vasthouden aan de automatische publieke labeling van de betrokkene met een civielrechtelijk bestuursverbod, dan dient de wetgever zich ervan bewust te zijn dat een gestigmatiseerde bestuurder na afloop van zijn bestuursverbod juridisch gezien weliswaar de vrijheid heeft om te ondernemen, maar dat een tweede kans hem feitelijk sociaal onmogelijk kan worden gemaakt. Het risico bestaat dat door de haast oneindige zoek- en geheugencapaciteit van het internet een kopie van de persoonsgegevens van de voormalige bestuurder een sluimerend elektronisch bestaan leidt tot het einde der tijden. ${ }^{95}$ Het civielrechtelijk bestuursverbod én de openbaarmaking ervan is onzes inziens alleen gerechtvaardigd in die gevallen waarin we als samenleving zeker niet willen dat de betrokkene tijdens het civielrechtelijk bestuursverbod als natuurlijke persoon handel drijft of na afloop van het bestuursverbod weer onderneemt met behulp van een rechtspersoon. Deze betrokkene verdient geen tweede kans.

93. Handelingen II 2014/15, nr. 97, item 6, p. 20; Aanhangsel Handelingen II $2017 / 18$, nr. 1665 , p. 2.

94. Philips heeft voorstellen gedaan hoe het civielrechtelijk bestuursverbod gehandhaafd kan worden zonder volledige openbaarheid. Gedacht kan worden aan een register dat slechts toegankelijk is voor de KvK en notarissen of op specifiek verzoek toegankelijk is voor aandeelhouders en commissarissen die twijfelen over de benoeming van een bestuurder of commissaris. Andere vormen van beperkte openbaarheid zijn denkbaar, zie: Philips 2013, p. 117.

95. L. van den Berge \& M. Neekilappillai, De eeuwige stem van de verdachte, AA 2013, p. 349. 